\title{
Predictors of response in patients with active systemic JIA (SJIA) receiving canakinumab: an exploratory analysis of pooled 12-week data
}

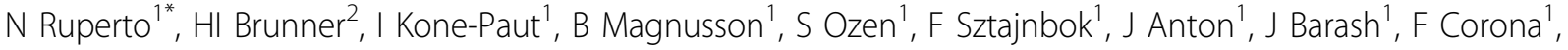 \\ K Lheritier ${ }^{3}$, C Gaillez ${ }^{3}$, A Martini ${ }^{1}$, D Lovell ${ }^{2}$
}

From 21st European Pediatric Rheumatology (PReS) Congress

Belgrade, Serbia. 17-21 September 2014

\section{Introduction}

Canakinumab (CAN), a selective, human, antiinterleukin-1 $\beta$ monoclonal antibody, has been shown to be efficacious in the treatment of SJIA (Ruperto et al. N Engl J Med 2012).

\section{Objectives}

To explore baseline demographics and clinical characteristics that are most predictive of response to CAN in CAN-naïve SJIA patients during the initial 12 weeks of therapy.

\section{Methods}

Data from 3 trials were pooled for this analysis. CANnaïve patients (pts; $\mathrm{n}=178$ ) aged $2-19$ years with active SJIA were enrolled and received sc CAN $4 \mathrm{mg} / \mathrm{kg} / \mathrm{month}$; Predictors of response (according to aACR $* 30,70$, and Inactive Disease [ID]) at Days (D) 15, 29, 57 and 85 were explored using univariate and multivariate logistic regression analyses. The candidate predictors (categorical variables) of CAN-response considered were: Age group, Gender, Prior NSAIDS (no/yes), Prior MTX(no/yes), Steroids $(0,>0-\leq 0.4 ;>0.4)$, Number of Active Joints $(\leq 10,11-\leq 20,>20)$ and Joints with Limitation of Motion $(\leq 10,11-\leq 20,>20)$, CRP (elevated/normal) at baseline and at D15. All candidate predictors with $\mathrm{p}<0.1$ in univariate analyses were included in the multivariate analysis. "ACR response plus absence of fever.

\section{Results}

By week 2 there was substantial clinical benefit with 102 pts (57\%) and 36 pts (20\%) achieving aACR70 and

\footnotetext{
${ }^{1}$ PRINTO-Istituto Gaslini, Genova, Italy

Full list of author information is available at the end of the article
}

ID, respectively; by week 12,108 pts (61\%) had aACR70 and 50 pts (28\%) ID. The multivariate analysis indicated that normal CRP at D15 is the only predictor significant (all $\mathrm{p}<0.05$ ) for ID at all time-points (Table 1 ).

\section{Conclusion}

This exploratory analysis suggests that CAN-naïve patients with normal CRP (i.e. $\leq 10 \mathrm{mg} / \mathrm{l}$ ) at Day 15, lower baseline steroid doses, low number of active joints, no prior anti-TNF or prior NSAID use are those most likely to achieve inactive disease up to 12 weeks.

\section{Disclosure of interest}

N. Ruperto Grant / Research Support from: To Gaslini Hospital: Abbott, Astrazeneca, BMS, Centocor Research \& Development, Eli Lilly and Company, "Francesco Angelini”, Glaxo Smith \& Kline, Italfarmaco, Novartis, Pfizer Inc., Roche, Sanofi Aventis, Schwarz Biosciences GmbH, Xoma, Wyeth Pharmaceuticals Inc., Speaker Bureau of: Astrazeneca, Bristol Myers and Squibb, Janssen Biologics B.V., Roche, Wyeth, Pfizer, H. Brunner Consultant for: Novartis, Genentech, Pfizer, UCB, AstraZeneca, Biogen, Boehringer-Ingelheim, Regeneron, Paid Instructor for: Novartis, Speaker Bureau of: Novartis, Genentech, I. Kone-Paut Grant / Research Support from: SOBI, Chugai, Consultant for: Pfizer, SOBI, Novartis, AbbVie, Cellgene, Chugai, B. Magnusson: None declared., S. Ozen Consultant for: Novartis (Turkey), Speaker Bureau of: Speaker's fee from SOBI, F. Sztajnbok Grant / Research Support from: Institutional grant (UERJ) for participating in the canakinumab trial., Speaker Bureau of: Novartis-Brasil, J. Anton Consultant for: Novartis, Speaker Bureau of: Novartis, J. Barash Grant / Research Support from: Investigator in the Canakinumab study sponsored by 
Table Inactive Disease - Multivariate logistic regression analysis on 12-week data

\begin{tabular}{|c|c|c|c|c|}
\hline Variable*, Odds Ratio $(95 \% \mathrm{Cl})$ & Day 15 & Day 29 & Day 57 & Day 85 \\
\hline CRP at Day 15 (elevated vs normal) & $0.20(0.07,0.55)$ & $0.14(0.04,0.41)$ & $0.26(0.10,0.66)$ & $0.31(0.12,0.82)$ \\
\hline Number of active joints $(11-\leq 20$ vs. $\leq 10)$ & $0.22(0.03,1.66)$ & $0.55(0.09,3.41)$ & $0.17(0.031,0.97)$ & $0.37(0.06,2.10)$ \\
\hline Number of active joints ( $\leq 10$ vs. $>20$ ) & $2.56(0.12,55.39)$ & $1.53(0.06,37.44)$ & $16.10(1.00,258.12)$ & $25.41(1.60,404.61)$ \\
\hline Prior NSAID treatment (no vs. yes) & $2.01(0.71,5.71)$ & $9.33(2.44,35.68)$ & $3.10(1.03,9.31)$ & $5.31(1.66,17.05)$ \\
\hline Steroid Level ( 0 vs. $>0.4 \mathrm{mg} / \mathrm{kg} /$ day) & $5.48(0.97,31.01)$ & $8.89(1.26,62.64)$ & $2.98(0.51,17.46)$ & $11.16(1.72,72.34)$ \\
\hline Steroid Level (>0.4 vs. $>0-\leq 0.4 \mathrm{mg} / \mathrm{kg} /$ day) & $0.32(0.08,1.29)$ & $0.41(0.09,1.82)$ & $0.81(0.25,2.60)$ & $0.13(0.03,0.57)$ \\
\hline Prior MTX treatment (no vs. yes) & $1.94(0.75,5.00)$ & $2.78(0.93,8.33)$ & $2.79(1.04,7.51)$ & $1.77(0.65,4.83)$ \\
\hline Prior anti-TNFs treatment (no vs. yes) & $1.83(0.52,6.49)$ & $3.62(0.77,17.00)$ & $2.01(0.63,6.38)$ & $3.64(1.04,12.77)$ \\
\hline
\end{tabular}

Values in bold are significant; *Significant in at least one time point

Novartis, F. Corona: None declared., K. Lheritier Shareholder of: Novartis, Employee of: Novartis Pharma AG, C. Gaillez Employee of: Novartis Pharma AG, A. Martini Grant / Research Support from: Bristol Myers and Squibb, Centocor Research \& Development,Glaxo Smith \& Kline, Novartis, Pfizer Inc, Roche, Sanofi Aventis, Schwarz Biosciences GmbH, I declare that the Gaslini Hospital which is the public Hospital where I work as full time employee has received contributions to support the PRINTO research activities from the industries above mentioned. OLD: Francesco Angelini S.P.A., Janssen Biotech Inc, Abbott. , Consultant for: Bristol Myers and Squibb, Centocor Research \& Development, Glaxo Smith \& Kline, Novartis, Pfizer Inc, Roche, Sanofi Aventis, Schwarz Biosciences GmbH, I declare that the Gaslini Hospital which is the public Hospital where I work as full time employee has received contributions to support the PRINTO research activities from the industries above mentioned., Speaker Bureau of: Abbott, Bristol Myers Squibb, Astellas, Boehringer, Italfarmaco, MedImmune, Novartis, NovoNordisk, Pfizer, Sanofi, Roche, Servier, D. Lovell Grant / Research Support from: National Institutes of Health- NIAMS , Consultant for: Astra-Zeneca, Centocor, Amgen, Bristol Meyers Squibb, Abbott, Pfizer, Regeneron, Roche, Novartis, UBC, Forest Research Institute, Horizon, Johnson \& Johnson, Speaker Bureau of: Novartis, Roche.

\section{Authors' details}

${ }^{1}$ PRINTO-Istituto Gaslini, Genova, Italy. ${ }^{2}$ PRCSG, Cincinnati, USA. ${ }^{3}$ Novartis Pharma AG, Basel, Switzerland.

Published: 17 September 2014

doi:10.1186/1546-0096-12-S1-012

Cite this article as: Ruperto et al.: Predictors of response in patients with active systemic JIA (SJIA) receiving canakinumab: an exploratory analysis of pooled 12-week data. Pediatric Rheumatology 2014

12(Suppl 1):012
Submit your next manuscript to BioMed Central and take full advantage of:

- Convenient online submission

- Thorough peer review

- No space constraints or color figure charges

- Immediate publication on acceptance

- Inclusion in PubMed, CAS, Scopus and Google Scholar

- Research which is freely available for redistribution

Submit your manuscript at www.biomedcentral.com/submit
Ciomed Central 